\title{
PENANGANAN SENGKETA PENGUASAAN TANAH HAK ADAT MELALUI PERADILAN ADAT SUMATERA BARAT
}

\author{
Hesty Wahyuni, ${ }^{1}$ Dian Aries Mujiburohman, ${ }^{2}$ Sri Kistiyah $^{3}$ \\ ${ }^{1}$ Kantor Pertanahan Kab. Dharmasraya, Jl. Lintas Sumatera KM. 5, Sumatera Barat \\ ${ }^{2,3}$ Sekolah Tinggi Pertanahan Nasional, Jl. Tata Bumi No. 5 Banyuraden, Yogyakarta \\ Koresponden email: wahyunihesty10@gmail.com
}

Naskah diterima: 25 Agustus 2021; revisi: 13 September 2021; disetujui: 13 September 2021

\begin{abstract}
In accordance with Article 1 paragraph (7) of the Regional Regulation of West Sumatra Province No. 16 of 2008 concerning ulayat land and its utilization, ulayat land is a piece of heirloom land along with the natural resources on it which obtained from generation to generation and is the right of the customary law community in the province of West Sumatera. The formulations that can be brought out are (1) What kind of conflict of customary land tenure occur in KAN (Nagari Customary Density) Niniak Mamak Nan Salapan Suku Padang City, West Sumatra Province. (2) How (KAN) Niniak Mamak Nan Salapan Tribe of Padang City, West Sumatra Province, resolves disputes over customary land rights. This study is an empirical legal research using socio-legal approach. Indigenous peoples' dissatisfaction with conflict settlement at the customary court level has caused their existence to become hazy. This article investigates a recognized type of legal pluralism in West Sumatra, as well as the significance of the Ministry of Agrarian Affairs and Spatial Planning/National Land Agency and KAN as Minangkabau customary courts, and the position of KAN's decision in the District Court. It is viewed from form and pattern analysis of land tenure conflict settlement in pusako district.
\end{abstract}

Keyword: customary land, KAN, Pusako land, customary court

\begin{abstract}
Abstrak: Tanah ulayat merupakan bidang tanah pusaka beserta sumber daya alam yang ada di atasnya dan di dalamnya diperoleh secara turun temurun merupakan hak masyarakat hukum adat di Provinsi Sumatera Barat sesuai Pasal 1 Ayat (7) Perda Provinsi Sumatera Barat Nomor 16 Tahun 2008 tentang Tanah Ulayat dan Pemanfaatannya. Rumusan yang diangkat adalah (1) Bagaimana bentuk sengketa penguasaan tanah hak adat di KAN (Kerapatan Adat Nagari) Niniak Mamak Nan Salapan Suku Kota Padang, Provinsi Sumatera Barat? (2) Bagaimana pola penyelesaian sengketa penguasaan tanah hak adat di KAN Niniak Mamak Nan Salapan Suku Kota Padang, Provinsi Sumatera Barat? Penelitian ini merupakan penelitian hukum empiris dengan pendekatan sosio-legal. Ketidakpuasan penyelesaian sengketa ditingkat peradilan adat oleh masyarakat hukum adat mengakibatkan keberadaannya semakin kabur. Tulisan ini menemukan suatu bentuk pluralisme hukum yang diakui di Sumatera Barat, dan kedudukan putusan KAN di Pengadilan Negeri, serta relevansi Kementerian ATR/BPN dan KAN sebagai peradilan adat Minangkabau. Hal tersebut di lihat dari analisis bentuk dan pola penyelesaian sengketa penguasaan tanah pusako.
\end{abstract}

Kata Kunci: tanah ulayat, KAN, tanah pusako, peradilan adat

\section{A. Pendahuluan}

Keberadaan tanah ulayat dan masyarakat hukum adat di Sumatera Barat terbukti diakui, karena telah diterbitkannya Perda Provinsi Sumatera Barat Nomor 16 Tahun 2008 tentang Tanah Ulayat dan Pemanfaatannya. Tanah ulayat ada yang beraspek publik-privat 
dan tanah ulayat yang beraspek privat (Simarmata, 2018). Adanya hak ulayat karena terciptanya hubungan hukum antara masyarakat adat sebagai subjeknya dan ulayatnya (objeknya) sehingga terwujudnya kewenangan bagi subjek untuk melakukan perbuatan hukum (Sembiring, 2018). Hal ini sejalan dengan amanat Pasal 67 Undang-Undang Nomor 41 Tahun 1999 tentang Kehutanan yang mengakui peradilan adat sebagai salah satu unsur adanya masyarakat hukum adat yang sebelumnya telah dihapus menurut UU Darurat Nomor 1 Tahun 1951 (Sarjita, 2005). Dalam pelaksanaan hak ulayat di lapangan sering menimbulkan permasalahan antar masyarakat adat yang biasa disebut dengan sengketa tanah adat. Penanganan sengketa tanah adat dipertegas oleh pemerintah dengan Pasal 45 Permen ATR/Ka.BPN Nomor 21 Tahun 2020 tentang Penanganan dan Penyelesaian Kasus Pertanahan terkait penyelesaian sengketa dan konflik oleh lembaga adat.

Menurut Firdaus dan Malau (2020) permasalahan sengketa tanah ulayat disebabkan antara lain karena adanya ketidakjelasan garis keturunan keluarga dalam sebuah ranji, keirian sosial dan ekonomi antar anggota dalam satu ranji (garis) keturunan. Sengketa tanah hak adat ini juga timbul saat proses pendaftaran tanah pertama kali pada Kantor Pertanahan Kota Padang. Hal ini sebenarnya dapat diselesaikan melalui peradilan adat nagari sebelum diproses pada Kantor Pertanahan, tetapi tidak dilakukan sebagaimana diamanatkan dalam Peraturan Walikota Padang Nomor 6 Tahun 2010 tentang Pedoman Penyelenggaraan Lembaga-Lembaga Adat di Kota Padang. Mengingat peradilan adat tidak memiliki kekuatan eksekutorial. Pelaksanaannya sering tidak membuahkan hasil karena keberadaannya tidak disebutkan dalam UU Nomor 48 Tahun 2009 tentang Kekuasaan Kehakiman. Namun, berdasarkan Peraturan Wali Kota Padang Nomor 5 Tahun 2020 tentang Lembaga Adat Di Kota Padang, dikatakan bahwa diakuinya keberadaan Kerapatan Adat Nagari sebagai peradilan adat dan lembaga adat Nagari. Kebanyakan sengketa penguasaan tanah adat yang muncul pada proses pendaftaran tanah pertama kali pada Kantor Pertanahan Kota Padang yang diselesaikan melalui mediasi. Namun, jika tidak mencapai kesepakatan maka penyelesaian akan dilimpahkan ke Kerapatan Adat Nagari (KAN). Berdasarkan Peraturan Daerah Provinsi Sumatera Barat Nomor 7 Tahun 2018 tentang Nagari, KAN merupakan lembaga perwakilan tertinggi di Nagari yang anggotanya perutusan ninik mamak dan bagian alim ulama Nagari, cadiak pandai, dan Bundo Kanduang, serta unsur parik paga dalam Nagari yang bersangkutan berdasarkan istilah adat salingka nagari.

Salah satunya sengketa pengaduan dari kaum Sutan Rang Kayo sebanyak 32 berkas pada KAN Niniak Mamak Nan Salapan kaum Suku antara Suku Nan Diateh dan Suku Nan Dibawah. Penyelesaian sengketa penguasaan tanah hak adat di setiap KAN berbeda, hal ini disebabkan oleh adat salingka nagari pada masing-masing daerah di Minangkabau seperti 
halnya KAN Niniak Mamak Nan Salapan Suku. Tanah yang dipersengketakan ini dikenal dengan tanah pacuan kudo. Tanah pacuan kudo yang dipersengketakan berada di Kecamatan Padang Selatan dengan luas $80.000 \mathrm{~m} 2$. Status tanah pacuan kudo banyak menuai persepsi terkait pengelompokkan tanah pusako yang menyebabkan multitafsir. Ini mengakibatkan kekaburan dalam pembagian harta pusako. Faktor penyelesaian melalui Kerapatan Adat Nagari sebagai peradilan adat sangat dibutuhkan karena sengketa penguasaan tanah pacuan kudo ini tidak mencapai kesepakatan dalam mediasi di Kantor Pertanahan Kota Padang. Dalam penelitian ini, penulis ingin mengetahui bentuk dan pola penyelesaian sengketa penguasaan tanah adat di KAN (Kerapatan Adat Nagari) Niniak Mamak Nan Salapan Suku Kota Padang, Provinsi Sumatera Barat.

Penelitian mengacu pada penelitian Yunus dan Ali Muddin (2019) mengenai penyelesaian sengketa tanah ulayat yang telah bersertifikat berdasarkan hukum adat malind-anim, mengkaji tentang sengketa tanah ulayat yang diselesaikan melalui peradilan adat/lembaga adat, di mana lembaga adat bukanlah lembaga yang diktator, tetapi sangat memberikan keleluasaan kepada masyarakat. Pitriani (2018) mengemukakan tentang penanganan sengketa hak milik atas tanah berdasarkan Hukum Adat di Desa Air Tenang Kecamatan Air Hangat, Kabupaten Kerinci. Penelitian ini fokus terhadap sengketa batas karena ketidakjelasan bukti-bukti kepemilikan. Rahmad (2017) menjelaskan penanganan sengketa batas tanah melalui peradilan adat di Gampong Ujong Lamie dan Alue Seupeng, Kab. Nagan Raya, Aceh fokus terhadap penyelesaian yang terstruktur mulai dari tingkatan terendah yang disebut gampong sampai dengan pengadilan mukim dengan cara mediasi, musyawarah dan negosiasi. Menurut Utama dan Aristya (2015) Keberadaan peradilan adat dan hakim adat perlu diatur lebih tegas mengenai pembagian kewenangan dengan peradilan negara sehingga tidak menimbulkan penafsiran yang berbeda diantara hakim.

Penelitian yang dilakukan oleh peneliti berdasarkan pada penelitian terdahulu. Beberapa kajian terdahulu tersebut dikemas sesuai permasalahannya masing-masing, akan tetapi belum ada yang menyentuh mengenai sengketa penguasaan tanah hak adat Sumatera Barat yang masih dalam proses pendaftaran tanah pertama kali, sehingga peneliti ingin mengkaji bentuk dan pola penyelesaian pasca mediasi yang dilakukan oleh peradilan adat nagari. Peneliti ingin menelaah penyelesaian pada KAN Niniak Mamak Nan Salapan Suku yang menaungi 4 (empat) Kecamatan yaitu: Padang Barat, Padang Timur, Padang Utara, dan Padang Selatan dengan ketentuan adat setempat. Hal tersebut bertujuan dapat meminimalisasi pengaduan sengketa penguasaan tanah hak adat melalui peradilan nagari dari aspek pertanahan dalam rangka percepatan pendaftaran tanah adat Sumatera Barat. 


\section{B. Metode Penelitian}

Penelitian ini menggunakan metode penelitian hukum empiris melalui pendekatan sosio-legal (Sonata, 2014). Penelitian ini mengkaji permasalahan berdasarkan regulasi, studi dokumen yang diimbangi dengan studi di lapangan. Penelitian ini dilakukan di Kerapatan Adat Nagari Niniak Mamak Nan Salapan Suku Kota Padang, Provinsi Sumatera Barat dan dikaitkan dengan data pada Kantor Pertanahan Kota Padang. KAN Niniak Mamak Nan Salapan Suku manaungi 4 (empat) Kecamatan yaitu: Padang Barat, Padang Timur, Padang Utara, dan Padang Selatan. Analisis data dilakukan dari penelusuran dokumen sengketa penguasaan tanah hak adat di Kantor Pertanahan Kota Padang melalui mediasi dan peradilan adat nagari dan wawancara penulis terhadap informan mengenai penanganan sengketa penguasaan tanah hak adat melalui peradilan adat Sumatera Barat pada KAN Niniak Mamak Nan Salapan Suku dihimpun kemudian dianalisis dengan cara interpretasi.

Hasil wawancara direduksi terkait penelusuran dokumen dan aturan perundangundangan terkait seperti Peraturan Daerah Provinsi Sumatera Barat Nomor 16 Tahun 2008 tentang Tanah Ulayat dan Pemanfaatannya dan Perda Provinsi Sumatera Barat Nomor 7 Tahun 2018 tentang Nagari serta Peraturan Menteri ATR/BPN Nomor 18 Tahun 2019 tentang Tata Cara Penatausahaan Tanah Ulayat Kesatuan Masyarakat Hukum Adat serta peraturan perundang-undangan lainnya. Selanjutnya data disajikan dari abstraksi sehingga dapat dilakukan penarikan kesimpulan.

\section{Dinamika Penguasaan Tanah Pacuan Kudo}

1. Bentuk Sengketa Penguasaan Tanah Pacuan Kudo

Sengketa penguasaan yang terjadi antara sesama anggota kaum yang merasa memiliki hak yang sama atas bidang tanah pacuan kudo. Bentuk sengketa tanah pacuan kudo terjadi antara induak bako dan anak pisang secara fungsional (Sarjita, 2005). Sengketa ini disebabkan oleh perbedaan pendapat mengenai status tanah pacuan kudo dan perkembangan keturunan dalam ranji sehingga menyebabkan ketidakjelasan dalam pembagiannya. Hal ini juga disebabkan oleh karena adanya ketidakseragaman dalam memahami pusako randah dan pusako tinggi. Harato Pusako Randah merupakan harta yang diperoleh dari satu atau dua kali keturunan dalam satu garis lurus yang diperoleh melalui pencaharian, pembelian dan taruko dapat diatur melalui Hukum Islam dan musyawarah dalam anggota adat (Rahmat 2019). Irsal Verry Idrus Dt. Lelo Sampono (2017) Harto Pusako Tinggi Merupakan harta pusaka yang diwarisi turun temurun dengan sistem matrilineal yang dimiliki oleh semua anggota kaum, seperti tertuang dalam pantun di bawah ini: 
Biriek-biriek tabang kasawah (birik-birik terbang ke sawah)

Dari sasak turun kahalaman (dari sasak turun ke halaman)

Dari niniek turun kemamak (dari ninik turun ke mamak)

Dari mamak ka kamanakan (dari mamak ke kemenakan)

Sengketa penguasaan ini terjadi di dalam lingkup wilayah KAN Niniak Mamak Nan Salapan Suku yang merupakan saksi sejarah Kota Padang. Berdasarkan Undang-Undang Nomor 9 Tahun 1956 tentang Pembentukan Daerah Otonom Kota-Besar Dalam Lingkungan Daerah Provinsi Sumatera Tengah (Sumatera Barat, Riau, dan Jambi) Nagari Padang termasuk salah satu kota besar yang selanjutnya disebut Kota Padang. Melihat perkembangan dan kemajuan Padang serta pemikiran pemerintah pada masa itu menjadikan Kota Padang sebagai ibukota Provinsi Sumatera Barat. Menindaklanjuti hal tersebut dikeluarkannya Pasal 3 Undang-Undang Nomor 17 Tahun 1980 tentang Perubahan Batas Wilayah Kota Madya Daerah Tingkat II Padang, mulanya Kota Padang terdiri dari 4 (empat) kecamatan dikenal dengan Nagari Padang lamo yaitu: 1) Padang Utara dengan pusat pemerintahan di Ulak Karang; 2) Padang Timur dengan pusat pemerintahan di Andalas Marapalam; 3) Padang Selatan dengan pusat pemerintahan di Seberang Padang; 4) Padang Barat dengan pusat pemerintahan di Belakang Tangsi. Kemudian ditambah 7 (tujuh) kecamatan pemekaran yang berasal dari nagari-nagari yang mengalami peningkatan status yaitu:

1. Kecamatan Koto Tangah dengan pusat pemerintahan di Lubuk Buayo

2. Kecamatan Nanggalo dengan pusat pemerintahan di Nanggalo

3. Kecamatan Kuranji dengan pusat pemerintahan di Pasar Ambacang

4. Kecamatan Pauh dengan pusat pemerintahan di Pasar Baru

5. Kecamatan Lubuk Begalung dengan pusat pemerintahan di Lubuk Begalung

6. Kecamatan Lubuk Kilangan dengan pusat pemerintahan di Indarung

7. Kecamatan Bungus Teluk Kabung dengan pusat pemerintahan di Teluk Kabung

Kerapatan Adat Nagari (KAN) Niniak Mamak Nan Salapan Suku disebut juga dengan Kerapatan Adat Nagari Niniak Mamak Nan Salapan Suku Nagari Padang 13 Kampung (Padang Lamo) sebagai KAN tertua di Kota Padang. KAN Niniak Mamak Nan Salapan Suku Nagari Padang 13 Kampung berdiri pada tahun 1667, tetapi keberadaannya pada saat itu belum begitu diterima. Seiring berjalannya waktu, kemunculan KAN Niniak Mamak Nan Salapan Suku Nagari Padang 13 Kampung diakui yang ditandai dengan adanya balai adat. Balai adat sudah didirikan pada tahun 1866 bersamaan dengan didirikan Mesjid Ganting sebagai masjid pertama di Nagari Padang. Pada tanggal 23 April 1922 diadakan rapat resmi dalam rangka pembentukan KAN Niniak Mamak Nan Salapan Suku Nagari Padang 13 Kampung yang dihadiri oleh Niniak Mamak, Cadiak Pandai, Alim Ulama, utusan Kab. 
Agam dan Kota Padang Panjang serta masyarakat adat se-Padang di Mesjid Ganting (arsip sejarah KAN Niniak Mamak Nan Salapan Suku Nagari Padang 13 Kampung, 2002).

Perjanjian Plakat Panjang (Lange Contract) pada tanggal 11 Oktober 1833 yang menyatakan bahwa adanya perubahan sistem pemerintahan dari sistem regent menjadi kampung di Nagari Padang. Dalam sistem ini Nagari Padang dibagi menjadi 13 kampung yang masing-masing dipimpin oleh kepala kampung. Marah Yulius sebagai sekretaris KAN Niniak Mamak Nan Salapan Suku Nagari Padang 13 Kampung menyatakan mulanya KAN ini menaungi 3 (tiga) kecamatan yaitu Kecamatan Padang Selatan, Kecamatan Padang Barat, dan Kecamatan Padang Timur, namun setelah terjadi pemekaran wilayah Padang pada tahun 1928 mengakibatkan masuknya sebagian dari Padang Utara ke wilayah KAN Niniak Mamak Nan Salapan Suku Nagari Padang menjadi 4 kecamatan di 13 kampung (wawancara, 25 Mei 2021). Mayoritas penduduk KAN Niniak Mamak Nan Salapan Suku Nagari Padang 13 Kampung berasal dari darek luhak nan tigo yaitu luhak Limo Puluah Kota, luhak Agam dan luhak Tanah Datar. Penduduk yang mendiami wilayah KAN Niniak Mamak Nan Salapan Suku Nagari Padang 13 Kampung ini biasa dikenal dengan masyarakat yang merantau ke daerah Padang.

Tabel 1. Kecamatan dan Kampung Dalam Kenagarian Padang

\begin{tabular}{lll}
\hline No & \multicolumn{1}{c}{ Kecamatan } & \multicolumn{1}{c}{ Kampung } \\
\hline \multirow{2}{*}{ Padang Utara } & 1. Kampung Alai Gunung Pangilun \\
& & 2. Kampung Ulak Karang \\
& 3. Alang Laweh \\
& & 4. Kampung Pasa Gadang \\
& & 5. Kampung Subarang Padang \\
& 6. Kampung Taluk Bayua \\
& & 7. Kampung Aia manih \\
& & 8. Kampung Jawo \\
& 9. Kampung Belakang Tangsi \\
& & 10. Kampung Pondok \\
& & 11. Kampung Sawahan \\
& 12. Kampung Andaleh Marapalam & 13. Kampung Parak Gadang \\
\hline
\end{tabular}

Sumber: Arsip KAN Niniak Mamak Nan Salapan Suku, 2002

KAN Niniak Mamak Nan Salapan Suku terdiri dari 8 suku yang masing-masing diketuai oleh seorang penghulu suku dan panungkek sebagai pembantu penghulu atau pengganti utama penghulu. 
Tabel 2. Nama Suku Kenagarian Niniak Mamak Nan Salapan Suku Nagari Padang

\begin{tabular}{llll}
\hline \multicolumn{2}{c}{ BODI CANIAGO } & \multicolumn{2}{c}{ KOTO PILIANG } \\
Suku Asal & Suku Di Padang & Suku Asal & Suku Di Padang \\
Caniago & Caniago Sumagek & Tanjung & Tanjung Sikumbang \\
& Caniago Mandalimo & & Tanjung Balai Mansiang \\
& Caniago Panyalai & & Tanjung Koto Piliang \\
Jambak & Jambak & Malayu & Malayu \\
\hline
\end{tabular}

Sumber: Arsip KAN Niniak Mamak Nan Salapan Suku, 2020

Sengketa tanah ulayat yang sering terjadi di KAN Niniak Mamak Nan Salapan Suku antar sesama anggota suku/kaum karena merasa dirugikan atau tidak mengetahui peralihan tanah ulayat kepada pihak lain. Sengketa penguasaan yang timbul karena tidak diakuinya salah satu anggota keluarga dalam suku/kaum. Adanya ketidakseimbangan penguasaan antar anggota suku/kaum karena status sosial dan keadaan ekonomi yang mengakibatkan kecemburuan atas banyaknya penguasaan pusako oleh masing-masing anggota dalam keluarga. Hal ini juga disebabkan oleh ketidakpahaman masyarakat adat dalam mengetahui batas-batas pusako suku/kaum serta rendahnya pengetahuan tentang pusako randah dan pusako tinggi yang berhubungan dengan peralihan tanah ulayat nantinya. Sengketa penguasaan pada KAN Niniak Mamak Nan Salapan Suku bersumber dari masyarakat adat secara langsung dan pelimpahan permasalahan adat dari Kantor Pertanahan Kota Padang seperti sengketa tanah pacuan kudo.

Gambar 1. KAN Niniak Mamak Nan Salapan Suku

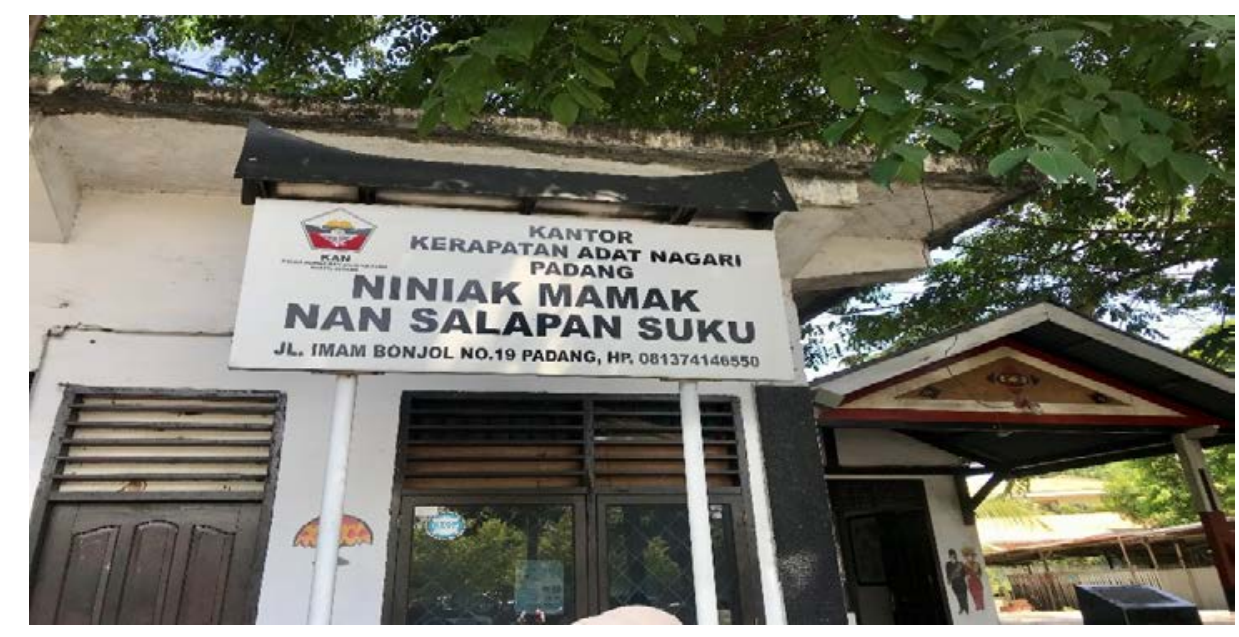

Sumber: Dokumentasi Penelitian, 2021

Sengketa tanah ulayat ini berawal dari tanah ulayat kaum. Tanah ulayat kaum adalah hak milik atas sebidang tanah beserta sumber daya alam yang ada di atas dan di dalamnya 
merupakan hak milik semua anggota kaum yang terdiri dari paruik/jurai yang penguasaan dan pemanfaatannya diatur oleh mamak jurai/mamak kepala waris sesuai amanat Perda Provinsi Sumatera Barat Nomor 16 Tahun 2008 tentang Tanah Ulayat Dan Pemanfaatannya. Tanah Ulayat suku beraspek merupakan tanah milik adat yang lebih beraspek privat (Warman, 2010). Sengketa ini terjadi antara Suku Nan Diateh dan Suku Nan Dibawah. Suku Nan Diateh yang merupakan induak bako dari Sutan Jalal yang biasa dikenal dengan anak pisang di Minangkabau. Induak bako merupakan panggilan di Minangkabau kepada keluarga ibu. Anak pisang adalah panggilan kepada keturunan dari pihak laki-laki di Minangkabau. Di Minangkabau hubungan anak pisang dan induak bako sangat dekat, dimana dikenal adanya tradisi penjemputan anak pisang oleh induak bako semasa masih kecil.

Sengketa tanah pacuan kudo berada di Kelurahan Seberang Padang, Kec. Padang Selatan dengan luas $80.000 \mathrm{~m} 2$. Tanah pacuan kudo Sebelah Timur berbatasan dengan Tanah Pusaka Zauhara; Sebelah Barat dengan Sungai Batang Arau/Tepi Air Ganting; Sebelah Utara dengan Sungai Batang Arau/Tepi Air Parak Gadang; Sebelah Selatan dengan Tanah Perparakan Nuni.

Sekretaris KAN Niniak Mamak Nan Salapan Suku bersama Sultan Syahruddin selaku Penghulu Suku Jambak, menjelaskan tanah pacuan kudo merupakan milik Suku Melayu yang bernama Zainudin. Semasa hidup beliau menguasai tanah tersebut. Pada tanggal 28 November 1896 beliau membuat wasiat Nomor 30 yang dihadapkan Tuan Carel Jaan Fuchter isinya menjelaskan bahwa tanah tersebut diwariskan kepada : 1/2 untuk anak kandungnya dan $1 / 2$ diperuntukkan kepada Puti Sal sebagai cucu sepanjang adat (wawancara, 25 Mei 2021).

Puti Sal menguasai tanah pacuan kudo dari tahun 1921, yang selanjutnya disewakan kepada perserikatan pacuan kudo sampai tahun 1930 dan diperpanjang lagi selama 10 tahun. Pada tahun 1930 terjadi sengketa antara keturunan dari Lobek anak kandung dari Zainudin yaitu Lobek. Semenjak tahun 1930 tanah pacuan kudo dikuasai oleh Puti Sal yang didapatkan dari $1 / 2$ bagian dari hibah wasiat Zainudin dan $1 / 2$ bagian lagi berasal dari hasil pembelian kepada anak Lobek anak dari Zainudin sesuai dengan vonnis Landraad Padang Nomor 188/1930. Sejak tahun 1930 tanah pacuan kudo secara keseluruhan dimiliki oleh Puti Sal sesuai dengan putusan KAN Nomor 07/KAN/ NM/8.Suku/Pdt/X-2020/PDG.

Sengketa penguasaan tanah pacuan kudo banyak menuai persepsi mengenai status tanahnya, antara lain:

a. Berdasarkan Berita Acara Mediasi Nomor 04.1/GM/SKP/ V/2019 pada pokok diskusi menerangkan bahwa Sutan Junda pada masa itu menjadi mamak kepala waris menyebutkan bahwa tanah pacuan kudo merupakan harta pusako tinggi yang 
didapatkan secara turun temurun yang diperkuat dengan Hasil mediasi KAN tanggal 4 Februari 2019. Namun, surat itu dicabut karena cacat administrasi dan adanya kekeliruan.

b. Berdasarkan civiel-Appel Nomor 88/1930 Vonnis Nomor 117/1930 di dalam pokok perkara Sutan Jamaluddin mengatakan bahwa tanah pacuan kudo merupakan harta pusako tinggi kaum Suku Nan Diateh adalah milik bersama di antara sesama kaum (komunal).

c. Berdasarkan ranji pada tanggal 17 Mei 2017, pihak Sutan Jalal yang beranggapan bahwa tanah pacuan kudo merupakan harta pencaharian yang identik sebagai harta pusako randah. Maka dari itu, pembagian harta pusako randah berdasarkan hukum faraidh atau secara islam.

d. Berdasarkan ranji pada tanggal 28 Januari 2018, pihak Sutan Jambang berasumsi bahwa tanah pacuan kudo peninggalan Puti Sal merupakan harta Pusako Tinggi. Didalam ranji tersebut menerangkan jurai secara matrilineal atau garis keturunan ibu. Peralihan hak harta pusako tinggi secara pewarisan adat yaitu matrilineal.

e. Putusan KAN Nomor 07/KAN/NM/8.Suku/Pdt/X-2020/PDG tanggal 12 Oktober 2020 menyebutkan bahwa tanah pacuan kudo seberang padang merupakan peninggalan alm. Puti Sal dan harta pencaharian yang didapatkan semasa hidup bersama suami dan anak-anaknya, dikenal dengan harta pusako randah di Minangkabau.

Pejabat KAN Niniak Mamak Nan Salapan Suku, Penghulu Suku Jambak dan Sekteraris KAN Niniak Mamak Nan Salapan Suku menjelaskan bahwa harta pusako randah tidak bisa berubah menjadi harta pusako tinggi. Hal ini disebabkan oleh hukum pewarisan yang digunakan pada saat peralihan haknya. Kongres Niniak Mamak, alim ulama, dan Cadiak Pandai tahun 1952 Di Bukittinggi dan Seminar tentang Hukum Tanah Dan Hukum Waris Adat Fakultas Hukum Universitas Andalas Padang tahun 1968, menjelaskan bahwa harta pusako tinggi diwariskan melalui hukum adat dan harta pusako randah diwariskan dengan Hukum Islam (wawancara, 25 Mei 2021).

Berdasarkan Peraturan Walikota Padang Pasal 1 Peraturan Walikota Padang Nomor 6 Tahun 2010 tentang Pedoman Penyelenggaraan Lembaga-Lembaga Adat Di Kota Padang disebutkan harta pusako tinggi disebut sebagai tambilang basi dan harta pusako randah diibaratkan dengan tambilang ameh. Pusako randah yang masih utuh tidak dibagi atau dijual sampai empat turunan menurut garis keturunan ibu, dapat menjadi harta pusako tinggi yang diusahakan dan diawasi oleh Penghulu Suku/Mamak Kapalo Waris. Peraturan ini dicabut dan tidak berlaku lagi pada tanggal 5 Juni 2020 mengingat dikeluarkannya Peraturan Walikota Padang Nomor 50 Tahun 2020 tentang Lembaga Adat Di Kota Padang. Di dalam 
Peraturan Walikota Padang Nomor 50 Tahun 2020 tentang Lembaga Adat Di Kota Padang dihapuskannya fungsi KAN dan tidak dijelaskan mengenai harta pusako dengan rinci seperti pada Peraturan Walikota Padang Nomor 6 Tahun 2010 tentang Pedoman Penyelenggaraan Lembaga-Lembaga Adat Di Kota Padang.

Kurnia Warman, Dosen Universitas Andalas Padang menjelaskan harta pusako tinggi dan harta pusako randah diwarisi secara matrilineal. Kelompok matrilineal pusako tinggi tidak mengetahui lagi asal tanah tersebut. Subjek pusako randah tidak sebanyak kelompok matrilineal pusako tinggi karena masing-masing paruik/jurai mengetahui pembagian dan peruntukannya (wawancara, 01 Juni 2021). Istilah Harta pusako randah identik dengan harta pencarian dimaksudkan karena pihak laki-laki di Minangkabau tidak akan menginginkan pembagian dari harta pencarian orang tuanya, kecuali dalam keadaan tertentu. Pembagian harta pencarian di Minangkabau dominan jatuh pada pihak perempuan. Harta pencarian bisa menjadi sumber bagi harta pusako randah. Terkadang praktiknya di lapangan menyamakan harta pusako randah dengan harta pencarian, tetapi secara hukum berbeda. Harta Pusaka (harato pusako) adalah harta kongsi perserikatan bersama oleh orang Minang yang setali darah seperti sawah, ladang, hutan dan sebagainya (Budiawan al., 2019).

2. Pola Penyelesaian Sengketa Penguasaan Tanah Pacuan Kudo

a. Peradilan Adat

Berdasarkan Pasal 12 Ayat (1) Perda Provinsi Sumatera Barat Nomor 16 Tahun 2008 tentang Tanah Ulayat Dan Pemanfaatannya sengketa penguasaan tanah pacuan kudo dikembalikan kepada KAN sesuai dengan daerah letak tanah berperkara. Hal tersebut dikarenakan mediasi di Kantor Pertanahan Kota Padang tidak mencapai kata sepakat dalam rangka penanganan kasus Sutan Jalal dengan Sutan Jambang tanggal 21 Maret 2019. Pedoman dalam pemeriksaan perkara/ sengketa oleh para penghulu di Kerapatan Adat Nagari (KAN) yang tunduk pada Undang-Undang Nan Duo Puluah yang dibagi menjadi Undang-undang Nan Salapan dan Undang-undang Nan Duo Baleh. Undang-Undang Nan Duo Puluah dengan rupa-rupa kesalahan dan kejahatan. Hukum dalam Nagari dikenal 3 (tiga) perkara yaitu "dicari dengan bicara, dicari menurut adat, dibandingkan dengan syarak" yang diibaratkan dengan:

Manimbang sami barek

Ma ukum samo adia

Ukum bana Manahan bandiang

Penentuan kesalahan dalam penjatuhan hukuman pada KAN Niniak Mamak Nan Salapan Suku yaitu berdasarkan Undang-Undang Nan Duo Puluah dimana jika ada suatu kesalahan tetapi tidak dijumpai pada Undang-Undang Nan Salapan atau Undang-Undang 
Nan Duo Baleh dan sebaliknya maka kesalahan tersebut tidak sah. Suatu kesalahan dikatakan sah apabila ditemukan pada delik Undang-Undang Nan Salapan dan Undang-Undang Nan Duo Baleh, yang dikenal dengan istilah:

Yang mencencang jua yang memberi pampas

Yang membunuh jua yang memberi diat

Yang berhutang jua yang membayar

Yang berpiutang jua yang menerima

Yang menghilangkan jua yang akan mengganti

Yang gawal jua akan menyesal

Penyelesaian sengketa tanah ulayat dengan peraturan adat sesuai dengan Surat Edaran Lembaga Kerapatan Adat Alam Minangkabau (LKAAM) Nomor 7/LKAAM-SB-VI-1985 tanggal 10 Juni 1985 dikenal dengan fatwa adat yaitu bulek aia dek pambuluah, bulek kato dek mufakaik. Menurut Utama dan Aristya (2015) makna dari fatwa tersebut ialah penyelesaian yang lebih mengutamakan pola musyawarah mufakat dalam pengambilan keputusan. Penyelesaian pertikaian sengketa maupun konflik dalam adat dapat diselesaikan dengan lembaga adat. Dari mulai mamak di lingkungan kaum sampai dengan penyelesaian ditingkat ninik mamak. Para mamak tertinggi yaitu ninik mamak secara bersama-sama sebagai pemangku adat. Penyelesaian pertikaian adat jika tidak dapat diselesaikan pada tingkat terendah (kaum) maka dapat diteruskan ke KAN sesuai amanat Peraturan Daerah Provinsi Sumatera Barat Nomor 16 Tahun 2008 tentang Tanah Ulayat dan Pemanfaatannya. Dalam perkara perdata adat di KAN Niniak Mamak Nan Salapan Suku Nagari Padang mengenai tanah ulayat diselesaikan secara adat dikenal dengan istilah bajanjang naik, batanggo turun. Maksud dari bajanjang naik, batanggo turun artinya penyelesaian dilakukan melalui lembaga adat pada tingkat yang lebih randah yaitu tingkat keluarga di rumah gadang oleh mamak kepala waris. Penyelesaian dilanjutkan pada tingkat suku yang akan diselesaikan antar penghulu suku dan hasilnya diharapkan dapat dipatuhi oleh setiap yang bersengketa (wawancara, 25 Mei 2021). Azas berjenjang mengandung mata rantai kekuasaan yang dipegang oleh jabatan. Pemecahan masalah harus dilakukan pada tingkatan terendah. Jika tidak terjadi penyelesaian akan diteruskan ke atas, selangkah demi selangkah sampai terjadi penyelesaian (Beckmann, 2000).

Sengketa tanah pacuan kudo termasuk dalam sengketa ulayat pada tingkat kaum yang merupakan tingkatan ulayat terandah di Minangkabau pada saat terjadi sengketa antara Puti Sal dan Sutan Jamaluddin tahun 1930. Namun, karena adanya perkembangan garis keturunan dalam ranji, dan perbedaan persepsi mengenai status tanah pacuan kudo menyebabkan tanah pacuan kudo menjadi sengketa tanah ulayat suku. Tahapan penyelesaian dilanjutkan oleh KAN pada tingkat nagari tetapi tidak tercapai kesepakatan. 
Pada tanggal 4 Februari 2019 telah diterbitkan sebuah surat KAN yang menyatakan bahwa sengketa dapat diteruskan ke pengadilan jika salah satu pihak merasa tidak puas berdasarkan Undang-Undang Nan Duo Puluah. Pada tanggal 12 Oktober 2020 KAN mengeluarkan putusan Nomor 07/KAN/NM/8.Suku/Pdt/X-2020/PDG yang menyatakan bahwa tanah pacuan kudo merupakan harta pusako randah dan mencabut surat KAN tanggal 4 Februari 2019. Berdasarkan dan sesuai dengan amanat Pasal 12 Ayat (2) Perda Provinsi Sumatera Barat Nomor 16 Tahun 2008 tentang Tanah Ulayat Dan Pemanfaatannya dijelaskan bahwa pihak-pihak yang bersengketa dapat mengajukan perkaranya ke pengadilan negeri.

b. Pengadilan Negeri

Menurut amanat Pasal 12 Ayat 2 Perda Provinsi Sumatera Barat Nomor 16 Tahun 2008 tentang Tanah Ulayat dan Pemanfaatannya, maka gugatan diajukan ke PN Kota Padang tanggal 27 Februari 2020 oleh Sutan Jalal gelar Rajo Lelo. Berdasarkan Surat Edaran Pengadilan Tinggi Nomor W.3.DA.HT.04.02-3633 tanggal 27 Mei 1985 Pengadilan Negeri di Sumatera Barat tidak boleh menerima sengketa mengenai sako, pusako dan tanah ulayat sebelum dibuktikan oleh putusan KAN oleh pihak penggugat. Namun seiring berjalannya waktu turut tergugat atas nama Rosa (sepupu penggugat) meninggal dunia.

Sidang telah dilakukan sebanyak 2x pada tanggal 28 April 2020 dan tanggal 5 Mei 2020. Namun pada persidangan kedua kuasa hukum penggugat mengajukan permohonan secara lisan yang menyatakan pencabutan perkara perdata Nomor 34/Pdt.G/2020/PN.Pdg karena sesuatu dan lain hal. Pencabutan perkara dapat dilakukan mengingat Pasal 271 alinea $1 R V$ (Reglement Op de Rechvordering) di mana penggugat dapat mencabut perkaranya, selama tergugat belum menyampaikan jawaban atas gugatan penggugat. Pencabutan gugatan tidak diperlukan ijin dari para tergugat (Vide Yurisprudensi MARI No.1841 K/Pdt/1984 tanggal 23 Nopember 1985). Hal tersebut ditambah lagi dengan permasalahan intern yang terjadi antara penggugat dengan pengacaranya. Hal tersebut menyebabkan penggugat mencabut gugatannya (wawancara, 25 Mei 2021).

c. Kantor Pertanahan Kota Padang

Penyelesaian di Kantor Pertanahan Kota Padang pasca tidak tercapainya kesepakatan dalam mediasi yang dilanjutkan ke ranah peradilan adat yaitu KAN Niniak Mamak Nan Salapan Suku. Dalam tahapan non-litigasi tersebut tercapai suatu rekomendasi untuk diteruskannya ke pengadilan negeri.

Berdasarkan putusan Nomor 34/Pdt.G/2020/PN.Pdg tanggal 6 Mei 2020, Kantor Pertanahan Kota Padang memberikan masa tenggang selama 60 hari untuk melakukan upaya hukum lanjutan. Namun, hal ini tidak dilaksanakan sesuai dengan SOP-nya oleh penggugat. Sesuai Peraturan Menteri Agraria Dan Tata Ruang/ Kepala Badan Pertanahan 
Nasional Republik Indonesia Nomor 11 Tahun 2016 tentang Penyelesaian Kasus Pertanahan pada saat itu, maka ATR/BPN melakukan suatu upaya berdasarkan ketentuan yang berlaku.

Berdasarkan aplikasi KKP Kantor Pertanahan Kota Padang tahun 2021 didapatkan sebanyak 21 berkas yang sudah selesai PBT (Peta Bidang Tanah) dan pengumuman (60 hari), 10 berkas masih dalam proses 1 berkas ditutup (aplikasi kkp, 2021). PBT yang sudah terbit dapat dilihat pada gambar di bawah ini:

Gambar 2. Peta Bidang Tanah Permohonan Legalitas Tanah Pacuan Kudo

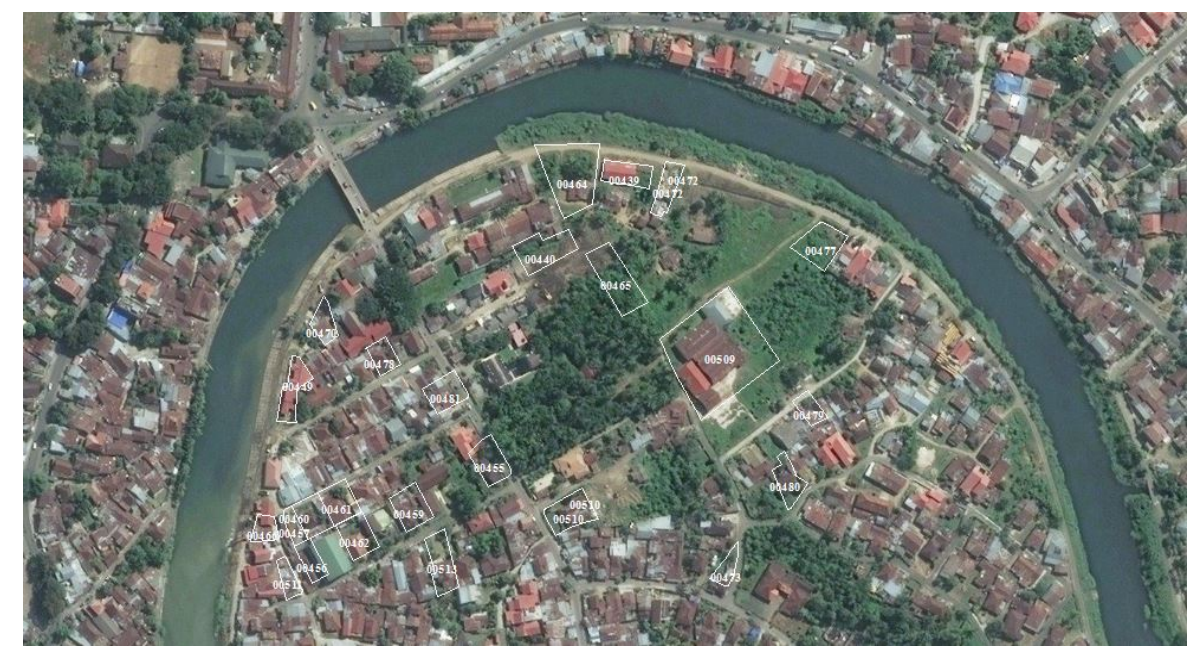

Sumber: Aplikasi KKP Kantor Pertanahan Kota Padang

\section{d. Kedudukan Putusan KAN Di Pengadilan Negeri dan Pluralism}

Menurut Reza Himawan Pratama, salah satu Hakim Perdata Pengadilan Negeri Kota Padang menjelaskan putusan peradilan adat merupakan sebuah kajian atau rekomendasi oleh pengadilan negeri untuk memutuskan suatu sengketa adat baik sako, pusako, maupun tanah ulayat (wawancara, 25 Mei 2021). Putusan peradilan adat Sumatera Barat yang dikenal dengan putusan KAN hanya sebagai kajian literatur di pengadilan negeri jika suatu perkara perdata adat diteruskan ke ranah litigasi. Jadi tidak secara langsung putusan KAN mutlak menjadi putusan akhir dari suatu perkara perdata adat.

Kurnia Warman, Dosen Universitas Andalas Padang berpendapat bahwa putusan pengadilan negeri Sumatera Barat linear dengan putusan KAN. Setiap putusan PN terkhusus mengenai tanah ulayat berbanding lurus dengan putusan KAN, meskipun putusan bukan sebagai acuan hakim di pengadilan negeri secara mutlak.

“Dari beberapa kasus secara sporadis dan teman-teman advokat mulai tingkat pertama, banding, sampai dengan kasasi Putusan Pengadilan Negeri linear dengan putusan KAN. Putusan KAN Menjadi alat bukti yang signifikan dalam membuktikan hukum adat dalam penyelesaian perkara di pengadilan negeri. Tidak otomatis putusan KAN dianulir oleh pengadilan negeri. Hakim menganggap apa yang diputus oleh KAN terhadap kasus konkrit itulah hukum adatnya karena hakim mengacu pada Pasal 
5 UUPA. Pengadilan negeri memeriksa putusan KAN yang menjadikan alat bukti bagi yang berperkara di pengadilan" (wawancara, 01 Juni 2021).

Surat Edaran Pengadilan Tinggi Nomor W.3.DA.HT.04.02-3633 tanggal 27 Mei 1985 tidak efektif seiring berjalannya waktu karena adanya Perda Provinsi Sumatera Barat Nomor 9 Tahun 2000 yang mencabut dasar hukum berdirinya KAN yaitu Perda Nomor 13 Tahun 1983 tentang Nagari (Kurnia Warman, 1 Juni 2021). Namun hakim tetap menerima semua gugatan yang masuk ke pengadilan negeri berdasarkan Pasal 10 Undang-Undang Nomor 48 Tahun 2009 tentang Kekuasaan Kehakiman yang menjelaskan bahwa hakim tidak boleh menolak untuk memeriksa, mengadili dan memutuskan suatu perkara dengan dalih hukumnya tidak ada. Ini menjadi dasar hakim untuk menerima semua perkara yang masuk ke pengadilan negeri.

Namun hal ini tidak berlaku pada sengketa pacuan kudo yang dilihat pada perbuatan hukum pihak penggugat. Pihak penggugat masih mengacu pada Surat Edaran Pengadilan Tinggi Nomor W.3.DA.HT.04.02-3633, di mana sengketa penguasaan tanah pacuan kudo tetap dibawa ke ranah non-litigasi (peradilan adat).

Putusan KAN menjadi alat bukti oleh pihak penggugat untuk menguatkan pembuktiannya secara adat di depan hakim. Bagi hakim putusan KAN di samping menjadi literatur, substansi putusan KAN sangat membantu dalam hal mencari solusi dari sengketa adat terkhusus sengketa tanah ulayat. Perbedaan utama antara prosedur pengadilan negeri dengan peradilan nagari (adat) berada dalam hal kebebasan pengadilan negeri yang cukup untuk menyesuaikan diri dengan prosedur-prosedur adat. Dengan alasan struktural para hakim tidak bersedia atau tidak mampu menyesuaikan diri dengan wawasan prosedur adat, sekalipun apabila mereka bebas melakukannya dari sudut pandang hukum negara (Beckmann 2000, 161).

Hal ini dikaitkan dengan teori pluralism terhadap penerapan hukum adat Sumatera Barat. Peraturan Daerah No. 9 Tahun 2000 tentang Ketentuan Pokok Pemerintahan Nagari merupakan berlakunya prinsip pluralisme hukum ini. Kebijakan ini menjadikan Sumatra Barat pada saat itu sebagai satu-satunya provinsi di Indonesia yang tidak lagi memakai sistem pemerintahan desa, tetapi sistem pemerintahan nagari yang dibentuk berdasarkan hak asal-usul dan adat istiadat setempat. Untuk menyesuaikan dengan perkembangan hukum pemerintahan daerah, Pemerintah Daerah Sumatra Barat (Pemda Sumbar) mengganti Perda Nagari 2000 dengan Perda No. 2 Tahun 2007 (Perda Nagari Sumbar 2007). Sistem pemerintahan nagari menyatukan antara wilayah administrasi pemerintahan dengan wilayah masyarakat hukum adat pada tingkat paling bawah dengan prinsip adat salika nagari, pusako salingka kaum (Warman, 2010). 
Hukum adat yang diangkat dalam penelitian ini adalah hukum adat telah dituliskan oleh KAN yang bersumber dari kebiasaan adat salingka nagari, pusako salingka kaum yang telah ditetapkan pada wilayah adat. Sebagaimana teori pluralism, maka Sumatera Barat menganut strong legal pluralism yang mana eksistensinya tidak bergantung dengan hukum negara. Keadaan strong legal pluralism di Sumatera Barat dilihat pada saat penyelesaian permasalahan adat terkhusus tanah ulayat yang dilakukan pada lingkungan suku/kaum dan penyelesaian secara adat di peradilan adat yang menggunakan hukum adat yaitu UndangUndang Nan Duo Puluah. Penyelesaian permasalahan yang dilakukan dengan musyawarah pada lingkaran suku/kaum merupakan kebiasaan dan tradisi masyarakat hukum adatnya. Strong legal pluralism juga dilihat pada saat pencapaian kesepakatan di tingkat KAN, maka putusan KAN menjadi dasar diteruskannya pendaftaran tanah milik adat di Kantor Pertanahan Kota Padang atau memilih penyelesaian pada jalur litigasi (wawancara, 7 Juli 2021).

Berdasarkan Pasal 45 Ayat (2) Peraturan Menteri Agraria Dan Tata Ruang/ Kepala Badan Pertanahan Nasional Republik Indonesia Nomor 21 Tahun 2020 tentang Penanganan Dan Penyelesaian Kasus Pertanahan terkait penyelesaian sengketa dan konflik oleh lembaga adat, yang harus diformalkan dalam bentuk akta otentik dan/atau didaftarkan di pengadilan. Hal ini dapat dicermati secara tidak langsung putusan lembaga adat tidak dapat digunakan sebagai dasar perdamaian sebelum didaftarkan pada notaris dan pengadilan. Secara teoritis ini merupakan keadaan menuju weak legal pluralism demi unifikasi hukum dengan adanya kondisi yang membentuk sebuah keberagaman secara nasional dengan tujuan menjaga eksistensi masyarakat hukum adat di Indonesia.

Dapat disimpulkan Adanya legal pluralism dengan tujuan adanya harmonisasi hukum negara dalam hal pemerintahan dan hukum adat. Kurnia Warman, mengungkapkan hukum agraria tentang tanah adat di Sumatera Barat telah terbukti legal pluralism-nya, merupakan suatu manifestasi baik dalam bentuk putusan hakim, peraturan daerah, peraturan nagari, desa atau program pemerintah. Sejalan dengan itu di mana UUPA merupakan unifikasi hukum yang memadukan hukum negara dan hukum adat sebagai sumbernya (pasal 5 UUPA) (wawancara, 01 Juni 2021).

\section{e. Relevansi KAN Dan Kementerian ATR/BPN}

Berpijak dari banyak kasus sengketa, konflik, dan perkara adat di Sumatera Barat. Kepala Seksi Pengendalian dan Penanganan Sengketa Kantor Pertanahan Kota Padang menyebutkan bahwa jika ada sengketa adat yang belum mencapai kesepakatan damai dalam mediasi di Kantor Pertanahan Kota Padang, maka penyelesaiannya akan dilimpahkan kepada KAN sebagai lembaga adat di Sumatera Barat (wawancara, 21 Oktober 2020). Hal 
tersebut sejalan dengan Pasal 45 Peraturan Menteri Agraria Dan Tata Ruang/ Kepala Badan Pertanahan Nasional Republik Indonesia Nomor 21 Tahun 2020 tentang Penanganan Dan Penyelesaian Kasus Pertanahan terkait penyelesaian sengketa dan konflik oleh lembaga adat, Aturan ini memiliki tujuan yang sangat tepat untuk menjaga eksistensi masyarakat adat di Indonesia.

Penyelesaian sengketa dan konflik melalui lembaga adat telah dilakukan oleh Kantor Pertanahan Kota/Kab di Sumatera Barat sebelum aturan ini diterbitkan. Dalam pelaksanaanya di lapangan peneliti rasa dapat dikolaborasi dengan strategi tertentu terkait percepatan penyelesaian sengketa dan konflik adat di Sumatera Barat. Dalam pelaksanaan kedepannya dapat dibuat semacam kerangka kerja antara lembaga adat dan Kementerian ATR/BPN seperti amanat Pasal 44 Ayat (4) aturan ini.

Dalam pelaksanaan Mediasi dapat menghadirkan ahli adat dari KAN sebagai lembaga adat dengan persetujuan para pihak. Hal tersebut menjadi salah satu yang dapat dilakukan sebagai suatu bentuk kolaborasi antara KAN dan Kementerian ATR/BPN, terkhususnya Kantor Pertanahan Kota/Kab di Sumatera Barat. Hal tersebut belum pernah dilakukan Kantor Pertanahan Kota Padang dan KAN Niniak Mamak Nan Salapan Suku khususnya (wawancara, 25 Mei 2021).

Sekretaris KAN Niniak Mamak Nan Salapan Suku berpendapat bahwa kolaborasi strategi itu tidak dapat dilaksanakan mengingat beberapa kewenangan KAN (wawancara, 25 Mei 2021). Seiring dengan itu Kepala Seksi Pengendalian dan Penanganan Sengketa Kantor Pertanahan Kota Padang, berpendapat bahwa masing-masing pihak antara KAN dan Kantor Pertanahan Kota Padang mempunyai kewenangan, maka dari itu Kantor Pertanahan Kota Padang tidak ingin mencampuri penyelesaian sengketa adat di ranah KAN (wawancara, 01 Oktober 2020).

\section{Kesimpulan}

Dari hasil penelitian di atas dapat disimpulkan bahwa bentuk sengketa tanah pacuan kudo antara induak bako dan anak pisang dapat dilihat secara fungsional, dimana sengketa ini disebabkan oleh perbedaan pendapat mengenai status tanah pacuan kudo dan perkembangan keturunan dalam ranji sehingga menyebabkan ketidakjelasan dalam pembagiannya. Hal ini juga disebabkan oleh karena adanya ketidakseragaman dalam memahami pusako randah dan pusako tinggi di lingkungan masyarakat hukum adat. Pola Penyelesaian sengketa tanah pacuan kudo diselesaikan melalui peradilan adat secara non litigasi yang diteruskan ke pengadilan negeri. Putusan peradilan adat linear dengan putusan pengadilan negeri, dimana putusan peradilan adat sebagai suatu bentuk rekomendasi dan pembuktian bagi 
penggugat di pengadilan negeri. Pola penyelesaian ini menggambarkan adanya pluralisme hukum yang diakui di Minangkabau. Dalam penyelesaian sengketa tanah ulayat di Sumatera Barat, Hukum Negara dan Hukum Adat saling mengakomodir satu sama lain.

\section{Daftar Pustaka}

Beckmann, K.V.B., (2000). Goyahnya tangga menuju mufakat. Jakarta: PT. Grasindo.

Budiawan, H., Farid, A.H., \& Sarjita (2019). Problematika Pendaftaran Tanah Hak Ulayat Masyarakat Hukum adat Di Sumatera Barat. dalam Lutfi, A.N., Utami, W. Salim, M.N., \& Dewi, A.R., (penyunting). Eksistensi, perubahan, dan pengaturan tanah ulayat/adat di Indonesia. Yogyakarta: STPN Press.

Firdaus, R \& Malau, H (2020). Penyelesaian Sengketa Tanah di Nagari Anduring Kabupaten Padang Pariaman. Jurnal Perspektif: Jurnal Kajian Sosiologi dan Pendidikan, 3(4), 699-710.

Idrus, I.V. (2017). Undang-undang nan duo puluah. Padang: Lembaga Kerapatan Adat Alam Minangkabau.

Pitriani, (2018). Penyelesaian sengketa hak milik atas tanah warga menurut hukum adat di desa air tenang kecamatan air hangat kabupaten kerinci. 16(1). Diakses pada tanggal 18 Januari 2021， dari https://www.researchgate.net/publication/334639441_ Penyelesaian_Sengketa_Hak_Milik_atas_Tanah_Warga.

Rahmad, S.S. (2017). Penyelesaian sengketa batas tanah melalui peradilan adat di gampong ujong lamie dan alue seupeng, kab. nagan raya, aceh. Jurnal Bidayah, 8(2),191-208

Rahmat, I (2019). Pengelolaan Harta Pusaka Tinggi Dalam masyarakat Adat Minangkabau (Studi di Kecamatan Batipuh Kabupaten Tanah Datar. Jurnal Bakaba, 8(1), 15-24

Sarjita (2005). Teknik \& strategi penyelesaian sengketa pertanahan. Yogyakarta: Tugu Jogja Pustaka.

Sembiring, J (2018). Dinamika pengaturan dan permasalahan tanah ulayat. Yogyakarta: STPN Press.

Simarmata, R. (2018). Transkrip Presentasi. dalam Shohibuddin, M, Luthfi, A.N., \& Utami, W. (penyunting) 2019. Meninjau ulang pengaturan hak adat. Yogyakarta: STPN Press.

Sonata, DL (2014). Metode penelitian hukum normatif dan empiris: karakteristik kahsa dari metode meneliti hukum. Jurnal Ilmu Hukum, 8(1), 15-35

Utama, T.S.S., \& Aristy, S.D.F. (2015). Kajian tentang relevansi peradilan adat terhadap sistem peradilan perdata Indonesia. Mimbar Hukum, 27(1), 57-67

Warman, K. (2010). Hukum Agraria Dalam Masyarakat Majemuk: Dinamika Interaksi Hukum Adat Dan Hukum Negara Di Sumatera Barat. Jakarta: HuMa. 
Yunus, A.dkk (2019). Penyelesaian Sengketa Tanah Ulayat Yang Telah Bersertifikat Berdasarkan Hukum Adat Malind-Anim. 41(3). Diakses pada tanggal 18 Januari 2021, dari https://ojs.unud.ac.id/index.php/kerthapatrika/article/download/53763/32902/ 